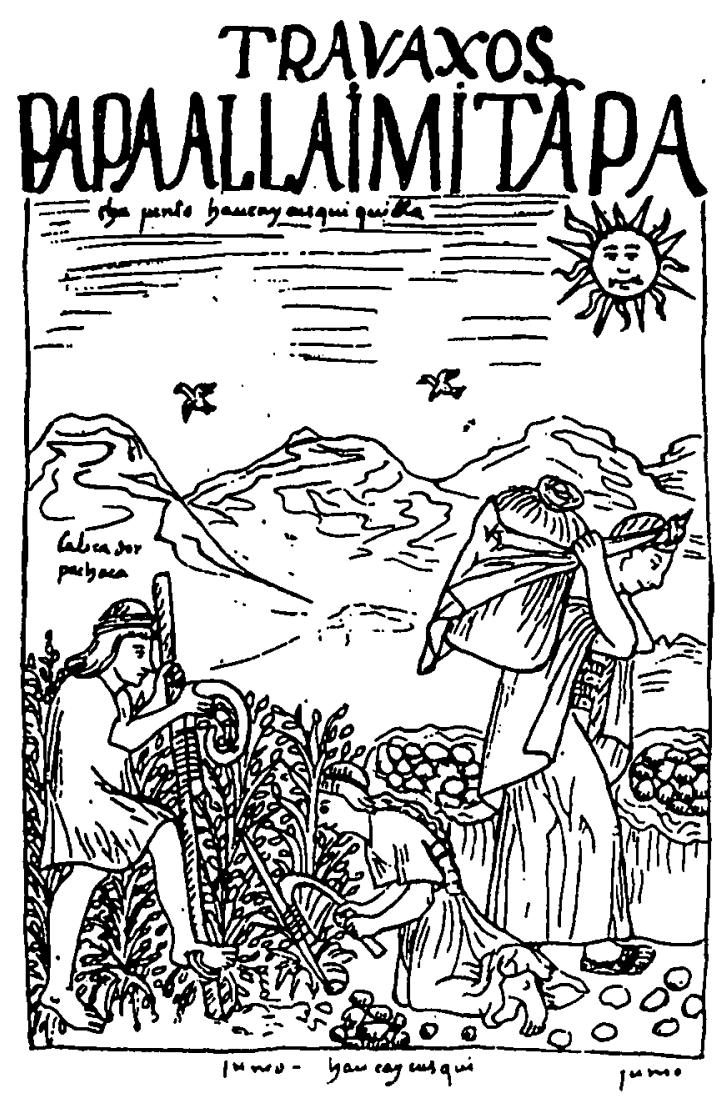

\title{
THE COUNTRYSIDE IN COLONIAL LATIN AMERICA
}

Edited by Louisa Schell Hoberman and Susan Migden Socolow Diálogos series

Cloth: $\$ 45.00$ Paper: $\$ 19.95$

\section{NATIONAL POPULAR POLITICS IN EARLY INDEPENDENT MEXICO, 1820-1847}

Torcuato S. Di Tella

Cloth: $\$ 55.00$

\section{A PEACEFUL AND WORKING PEOPLE}

Manners, Morals, and Class Formation in Northern Mexico William E. French

Cloth: $\$ 40.00$ 


\section{CAMBRIDGE}

The Kingdom of Quito, 1690-1830

The State and Regional

Development

Kenneth J. Andrien

This volume examines the impact of Spanish colonialism on patterns of development in the Kingdom of Quito (modern Ecuador).

£30.00 net HB $052148125^{\circ} 208$ pp.

Cambridge Latin American Studies $\mathbf{8 0}$

\section{NOW IN PAPERBACK stanford from Industry and CAMlBumere \\ Underdevelopment \\ The Industrialization of Mexico, 1890-1940 \\ Stephen H. Haber}

'This is an outstanding book that should be required reading for anyone wishing to gain a deeper understanding of the economic problems now facing the Mexican government.'

Journal of Third World Studies f10.95 net PB 0804725861256 pp.

\section{Between \\ Reform and \\ Revolution \\ Political Struggles in the Peruvian \\ Andes, 1969-1991 \\ Linda J. Seligmann}

A study of the effects of agrarian reform and civil war on the lives and sense of identity of a Peruvian peasant community.

$\begin{array}{llll}\text { f30.00 net } & \mathrm{HB} & 0804724423 & 304 \mathrm{pp} . \\ \text { E10.95 net } & \mathrm{PB} & 0804724431 & \end{array}$

Power and Violence in the Colonial City

Oruro from the Mining

Renaissance to the Rebellion of Tupac Amaru (1740-1782)

Oscar Cornblit

Translated by Elizabeth Ladd Glick Based on a study of the mining city of Oruro, this book examines the characteristics of political power in the cities of the colonial Spanish Empire.

f35.00 net HB $052144148 \times \quad 250 \mathrm{pp}$.

Cambridge Latin American Studies 76

\section{Roots of Stantord from Identity Canirimit: Language and Literacy in Mexico Linda King \\ This book attempts to discover why so many Mexican Indians are illiterate today despite a long-standing indigenous literary tradition. f30.00 net HB 0804721211288 pp.}

NOW IN PAPERBACK Stanford from

\section{Dangerous}

Cimisilut:

\section{Encounters}

Meanings of Violence in a Brazilian City

\section{Daniel Touro Linger}

This book examines violence in Sāo Paulo, looking at two conceptually linked forms of perilous face-to-face encounters: Carnival and briga. f11.95 net PB $0804725896 \quad 300 \mathrm{pp}$.

Stanford University Press books are distributed outside North America by Cambridge University Press
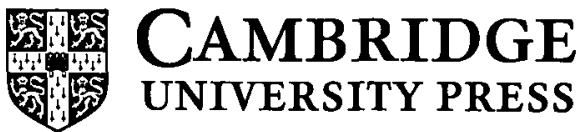

The Edinburgh Building, Cambridge CB2 2RU 


\section{NEW LATIN-AMERICAN}

\section{LITERATURE TITLES}

\section{THE UNDERDOGS}

Mariano Azuela

Translated by E. Munguia, Jr.

Foreword by Ana Castillo

Ten years after its publication in a small El Paso paper, The Underdogs achieved worldwide renown as the greatest novel of the Mexican Revolution. $152 \mathrm{pp}$.

Signet Classic

$0-451-52625-2$ $\$ 4.95$

\section{OF LOVE AND OTHER DEMONS}

Gabriel García Márquez

Translated by Edith Grossman

"García Márquez tells a story of forbidden love, but he demonstrates once again the vigor of his own passion: the daring and irresistible coupling of history and imagination."-Time. "Demonstrates that one of the masters of the form is still working at the height of his powers."-The New Yonk Times. 160 pp.

Penguin 0-14-025636-9 \$11.95

\section{REECKONING OF ANGELS}

Alfredo Véa, Jr.

A murder, a suicide, and what appears to be a bizarre case of divine intervention in present-day San Francisco all lead back to a killing in a migrant farmworker's camp in Stockton more than thirty years ago. $336 \mathrm{pp}$.

Dutton $\quad 0.525-94077-4 \quad \$ 23.95$ Avallable July 1996

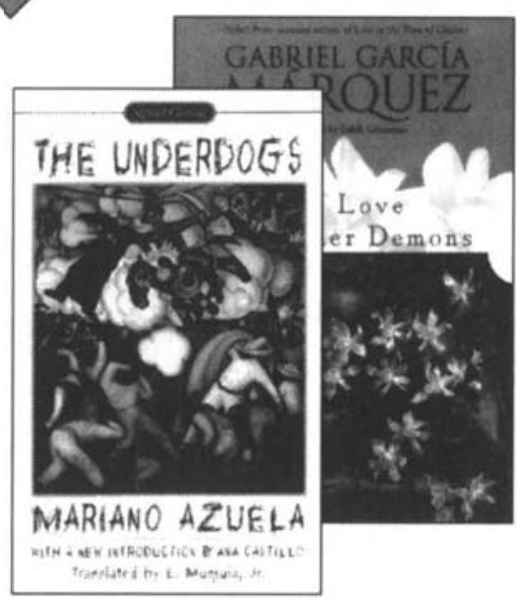

STREETS OF FIRE

Soledad Santiago

Originating as a hugely popular serial novel in New York Neusday, Streets of Fire is the vibrant, exciting tale of three Latina women in New York City. $320 \mathrm{pp}$.

Dutton $\quad 0-525-94078-2 \quad \$ 23.95$

THE EMPIRE'S OLD CLOTHES What the Lone Ranger. Babar, and Other Innocent Heroes Do to Our Minds Ariel Dorfman

Essential reading for those fascinated by the mass media or for anyone wanting to explore the meanings underlying the West's popular cultural icons. $240 \mathrm{pp}$.

Penguin orlginal 0-14-025637.7

$\$ 12.95$ Avallable June 1996

For a FREE Literature catalog, please call 212/366-2372 $P E N G \cup$ I $\mathrm{N}$ S A 


\section{The Enchanted Amazon Rain Forest: Stories from a Vanishing World}

NIGEL J. H. SMITH

"A masterpiece. ... In beautiful and readable prose, the author has deftly shown how folk beliefs, myths. and superstitions regulate lives and activities in primitive societies and how they often contribute to environmental conservation."-Richard Evans Schultes, Harvard Botanical Museum 208 pp. Cloth, $\$ 29.95$

Gender, Politics, and Poetry in TwentiethCentury Argentina JILL S. KUHNHEIM

"What an intelligent writer! ... [Kuhnheim] situates Orozco against a series of literary predecessors and inheritors, with quite an original method. ... The chapters on Eliot, Girondo, Pizarnik, and recent female poets give a new reading of $\mathrm{Ar}$ gentine poetry, and Latin American poetry by extension."

-Gwen Kirkpatrick, University of California, Berkeley 208 pp. Cloth, \$39.95

\section{Afro-Cuban Religious Experience: Cultural Reflections in Narrative EUGENIO MATIBAG}

"An important contribution to the field of Afro-Cuban beliefs and its impact on contemporary Cuban literature."-Antonio Benitez-Rojo, Amherst College April. 352 pp. Cloth, $\$ 49.95$

\section{Social and Economic Reform in Ecuador: Life and Work in Guayaquil} RONN F. PINEO

"A pioneering study which fills an important gap in the social and economic history of Ecuador. ... An admirable contribution to urban social history in Latin America."-John Martz, Penn State University 256 pp. Cloth, $\$ 49.95$

\section{Music of the Warao of Venezuela:} Song People of the Rain Forest DALE A. OLSEN

"An excellent balance of musical, cultural, historical, and mythological analysis. ... A major contribution to the organology of Latin American Native American music-cultures."-John M. Schechter. University of California, Santa Cruz

April. 432 pp. Compact disk. Cloth, $\$ 49.95$

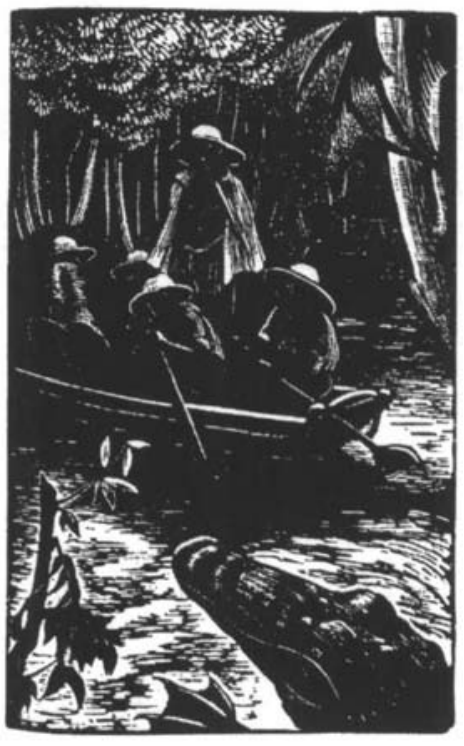

Jewish Voices in Brazilian Literature: A Prophetic Discourse of Alterity NELSON H. VIEIRA

"The first major book in English on this fascinating and complex culture. Vieira provides an exciting introduction for all readers interested in contemporary literary culture-Jewish/feminist/ South American/post-colonialit is all here."-Sander L. Gilman, University of Chicago 264 pp. Cloth. $\$ 49.95$

\section{The Sandinista Legacy:} Lessons from a Political Economy in Transition ILJA A. LUCIAK

"Important contributions not only to the comparative literature of regime transitions (particularly 'post-socialist' transitions), but also to the study of Nicaragua and Central America." - Richard Tardanico, Florida International University 258 pp. Cloth, $\$ 49.95$

Above: A caiman surprises fishermen along the Madeira River, in "The Enchanted Amazon Rain Forest" (from H.M. Tomlinson, "The Sea and the Jungle," London: Duckworth, 1930).

Order through full-service book stores or with VISA or $M / C$ toll free: 1-800-226-3822.

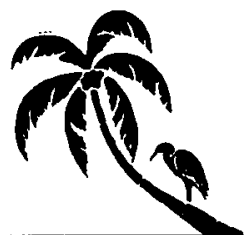

\title{
UNIVERSITY PRESS OF FLORIDA
}

\author{
GAINESVILIE. TALLAHASSEE, TAMPA, BOCA RATON, PENSACOLA, ORLANDO. MIAMI. JACKSONVILIE
}




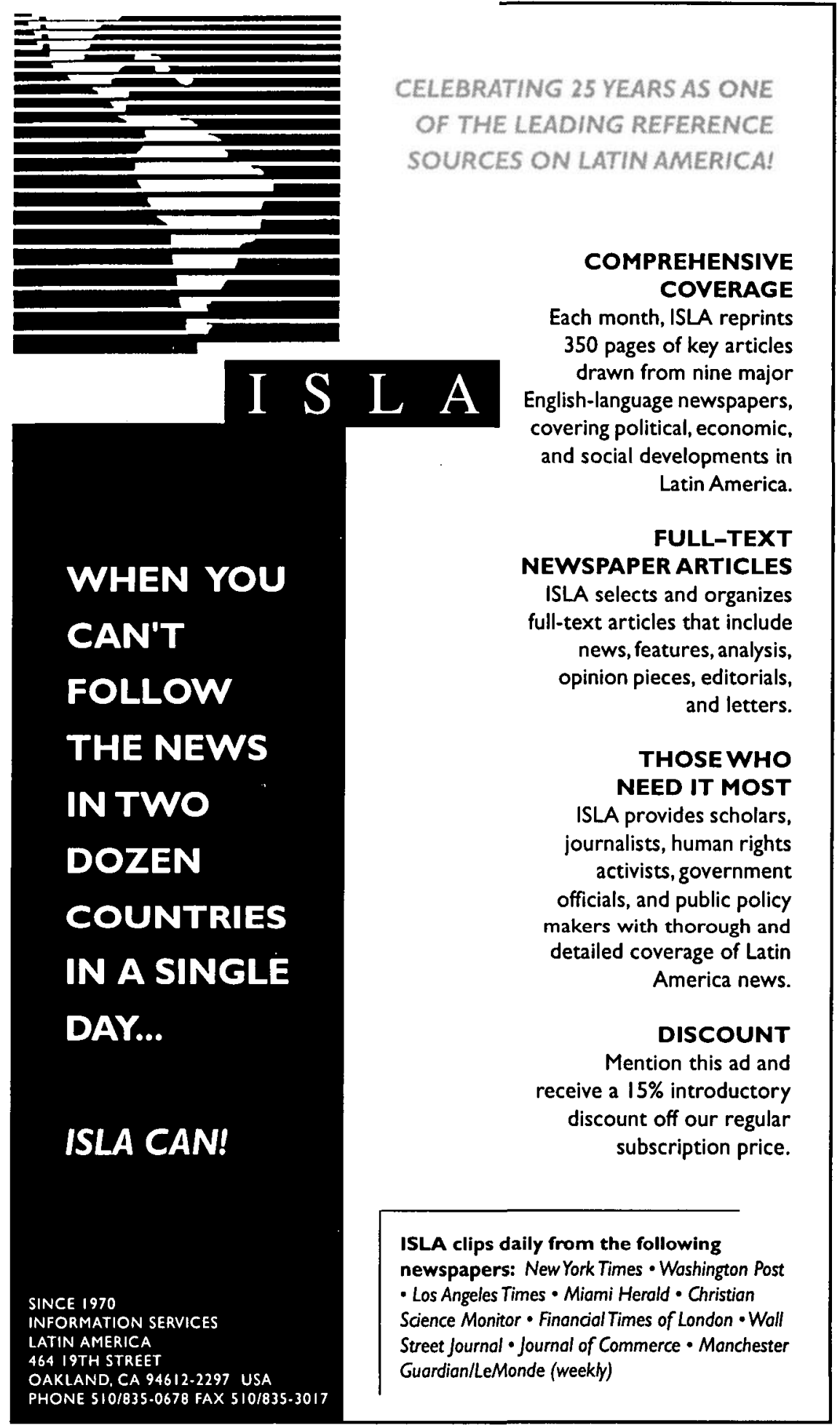




\begin{tabular}{|c|c|}
\hline \% r. & $P r=s / s$. \\
\hline $\begin{array}{l}\text { Theories of Dependent } \\
\text { Foreign Policy } \\
\text { The Case of Ecuador in the } 1980 \text { s } \\
\text { Jeanne A. K. Hey } \\
\text { How do economic weakness and } \\
\text { dependence influence foreign policy } \\
\text { decisions and behaviour in third world } \\
\text { countries? Hey's study examines this } \\
\text { complex and enduring question by } \\
\text { reviewing current competing theories } \\
\text { and undertaking some interesting case } \\
\text { studies from Ecuador. The discussion } \\
\text { borrows from a wide range of } \\
\text { theoretical traditions including realism, } \\
\text { dependency theory, and regional studies } \\
\text { and applies them to foreign policy } \\
\text { behaviour in Ecuador under the two } \\
\text { separate regimes of Osvaldo Hurtado } \\
\text { and León Febres Cordero. } \\
280 \text { pages, } £ 21.00 \text { paper }\end{array}$ & $\begin{array}{l}\text { Theory and Practice in the } \\
\text { Nicaraguan Revolution } \\
\text { Bruce E. Wright } \\
\text { Even in the period following the } \\
\text { electoral defeat of the Sandanista } \\
\text { National Liberation Front (FSLN) } \\
\text { in } 1990 \text {, the revolution of } 1979 \\
\text { continues to have a profound effect } \\
\text { on the political economy of Nicaragua. } \\
\text { Wright's study, which is based on } \\
\text { interviews with people from all walks } \\
\text { of life as well as on the large volume } \\
\text { of literature in both English and } \\
\text { Spanish, focuses on the FSLN } \\
\text { understanding of the relation between } \\
\text { the state, the party, and mass actors } \\
\text { and the nature of social classes. } \\
320 \text { pages, } £ 22.00 \text { paper }\end{array}$ \\
\hline
\end{tabular}

\section{Maglcal Reallsm}

Theory, History, Community

Lois Parkinson Zamora and

Wendy B. Faris, editors

In this critical anthology, the first of its kind, the editors show magical realism to be an international movement-rather than an exclusively regional trend-with a wideranging history and a significant influence among the literatures of the world.

In essays on texts by writers as diverse as Toni Morrison, Günter Grass, Salman Rushdie, Derek Walcott, Abe Kobo and many others, magical realism is examined as a worldwide phenomenon.

$592 \mathrm{pp}, 11$ illus., $£ 21.95 \mathrm{pb}, £ 56.95 \mathrm{hb}$

\section{The Postmodernism Dehate In Latin America}

John Beverley, José Oviedo, and Michael Aronna, editors

This collection explores the Latin American engagement with postmodernism, less to present a regional variant of the concept than to situate it in a transnational framework. $336 \mathrm{pp}, £ 14.95 \mathrm{pb}, £ 45.50 \mathrm{hb}$
Ethniclty, Markets, and Migration In the andes

At the Crossroads of History and Anthropology

Brooke Larson, Olivia Harris, and Enrique Tandeter, editors

This volume overturns this widely held assumption that Andean peasants are isolated subsistence farmers "resistant" to money and different markets in the region, and puts in its place a new perspective as it explores the dynamic between Andean cultural, social, and economic practices and the market forces of a colonial and postcolonial mercantile economy. 432pp, $£ 17.95 \mathrm{pb}, £ 55.00 \mathrm{hb}$

\section{Enttendes?}

Queer Readings, Hispanic Writings

Emilie L. Bergman and

Paul Julian Smith, editors

$480 \mathrm{pp}, £ 17.95 \mathrm{pb}, £ 50.00 \mathrm{hb}$

\section{DUXE UNUERSTY PRESS}

Academic \& University Publishers Group

1 Gower Street, London WC1E 6HA

Telephone: (0171) 5803994 


\section{Unted States Pollcy In Latin Amerlca}

\section{A Decade of Crisis and Challenge EDITED BY JOHN D. MARTZ About the previous edition: "A gem, an authoritative handbook on U.S. policy." Foreign Affairs}

This completely new work surveys U.S. policy for the past decade on topics of relevance to Latin America (such as trade, drugs, immigration, and armed insurrection).

$£ 52.50 \mathrm{hb} / £ 23.95 \mathrm{pb}$

\section{The New Latth American Milssion Histopy}

EDITED BY ERICK LANGER AND ROBERT H. JACKSON

The new mission historians examine cases from throughout the hemisphere-from the Andes to northern Mexico to California - in an effort to find patterns in the contact between the European missionaries and the various societies they encountered. E32.95 hb/E15.95 pb

\section{The Struggie for}

\section{Democracy in Chile}

Revised Edition

EDITED BY PAUL W. DRAKE AND NÁN JAKSÍC

About the first edition:

"A first-rate and timely anthology that enhances the reader's understanding of the prolonged and difficult transition to civilian rule in Chile." - The Americas $£ 21.50 \mathrm{pb}$
Women, Feminlsm, and 8oclal Change in Argentina, Chile, and Uruguay, 1890-1840

\section{ASUNCION LAVRIN}

Lavrin recounts changes in gender relations and the role of women in each of the three countries, thereby contributing an enormous amount of new information and incisive analysis to the histories of Argentina, Chile, and Unuguay.

$£ 57 \mathrm{hb}$

\section{Sex and Danger in \\ Buenos Alres}

Prostitution, Family, and

Nation in Argentina DONNA J. GUY

"The author's goal-to show the 'relationship of female sexual commerce to family, class, and nation'-is realized in a very readable analysis of mid-nineteenthto mid-twentieth-century Argentina from the perspective of the underworld of prostitutes, bordellos, and international white slavery rings."

Hispanic American Historical Review $£ 11 \mathrm{pb}$
University of Nebraska Press c/o Academic \& University Publishers Group 1 Gower St. London WC1E 6HA

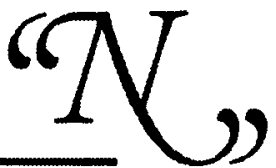




\begin{tabular}{|l|l|}
\hline $\begin{array}{l}\text { West Indian Workers and the } \\
\text { United Fruit Company in }\end{array}$ & $\begin{array}{l}\text { Latin American } \\
\text { Underdevelopment }\end{array}$ \\
Costa Rica, 1870-1940 & A History of Perspectives in the \\
Univa Chomsky & James William Park \\
Aviva Chomsky provides a superb & With this penetrating study, James \\
historical review of the development of & William Park provides the first \\
the Costa Rican banana industry, the & comprehensive account of nearly a \\
founding of the United Fruit Company, & century of U.S. thinking on the \\
and its procurement of a Jamaican & reasons for Latin America's apparent \\
labour force. She closely examines the & "backwardness, from 1870, when \\
company's policies with regard to its & the U.S. debated annexation of the \\
workers-its work rules and working & Dominican Republic, through the \\
conditions, the treatment of labourers & 1960s, with the implementation of \\
with respect to housing, medical care, & John F. Kennedy's doomed Alliance \\
and other matters-and its role within & for Progress. \\
the larger framework of Costa Rican & 312 pages, $£ 35.00$ cloth \\
society and politics. & \\
312 pages, $€ 32.95$ cloth & \\
\hline
\end{tabular}




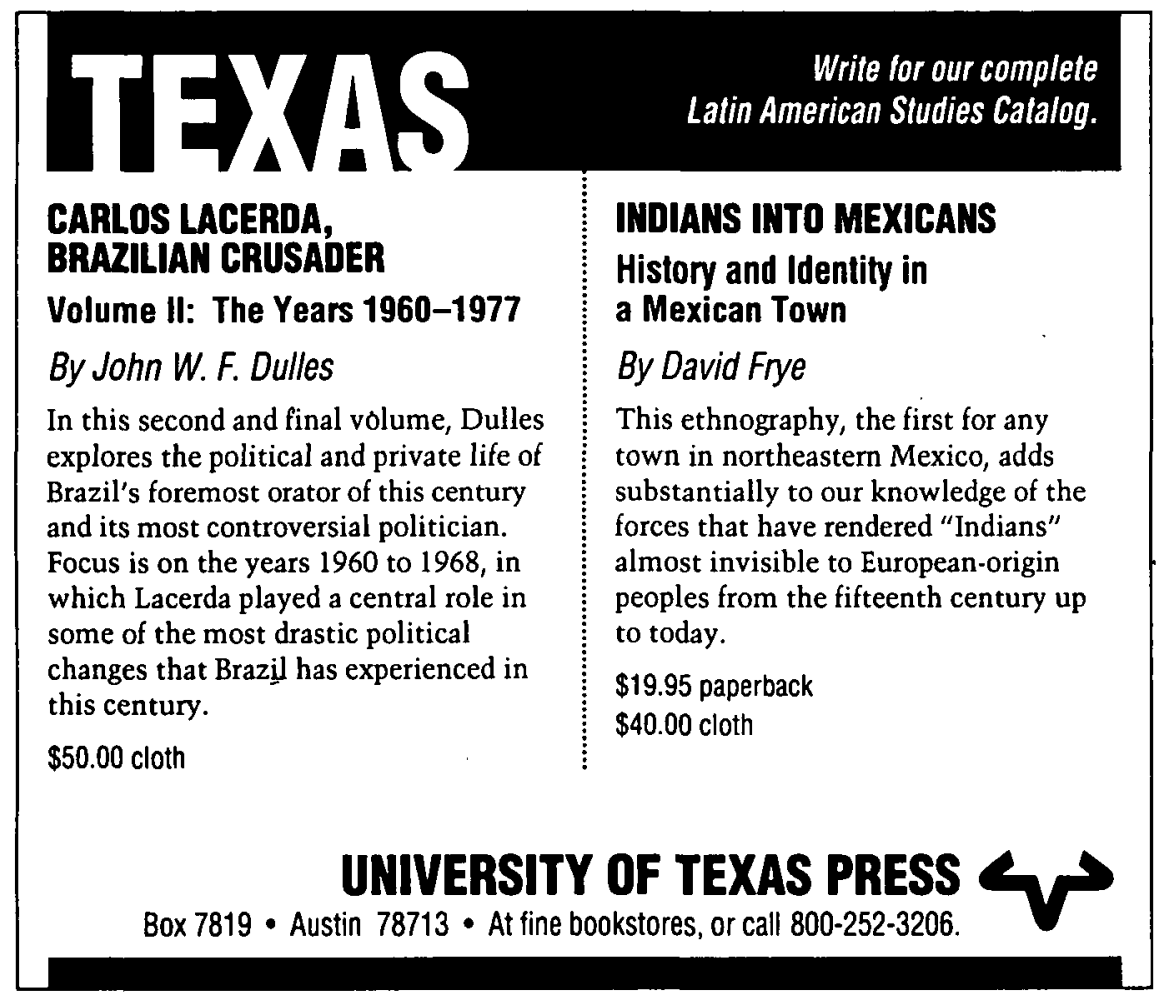




\section{E X I C A N $S T$ U D I E S}

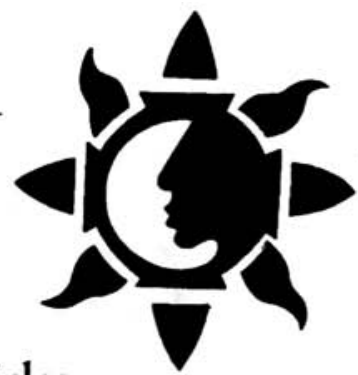

A biannual journal featuring articles in either English or Spanish which examine cultural, historical, political, social, economic, and scientific factors affecting Mexico's development.

"The major source for the literature on trends in Mexican scholarship." Roderic Ai Camp, Tulane University

Subscriptions:

Individuals, \$23; Institutions, \$49; Students, \$16 Single issues:

Individuals, \$12; Institutions, \$25

Send orders to:

University of California Press

Journals Division

2120 Berkeley Way \#5812

Berkeley, CA 94720-5812

FAX MC/VISA orders to 510/642-9917

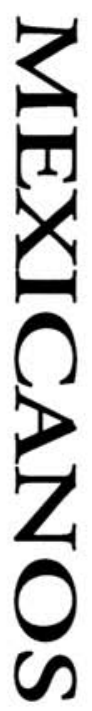




\section{NOTES FOR CONTRIBUTORS}

The Joumal of Latin American Studies is published three times a year, in February, May and October. Its editorial offices are located in the Institute of Latin American Studies, University of London. The editorial board includes representatives of the Centres or Institutes of Latin American Studies in the Universities of Cambridge, Essex, Glasgow, Liverpool, London and Oxford.

The scope of the Journal is the study of Latin America from the standpoint of the social sciences (including history and international relations). Articles on literature and the arts are not normally included, but the editors are pleased to consider contributions in the field of intellectual and cultural history. Articles with an inter-disciplinary approach are particularly welcome.

When an article has been accepted for publication, the author is strongly encouraged to send a copy of the final version on computer disk (Apple Macintosh or IBM compatible PC) together with the hard copy typescript, giving details of the wordprocessing software used (Microsoft Word or Word Perfect). However, the publisher reserves the right to typeset material by conventional means if an author's disk proves unsatisfactory.

Contributions are invited from all parts of the world. Articles should generally not be more than 8000 words long. The article should be accompanied by an abstract of not more than 100 words. Two copies typed with double spacing should be submitted. A style sheet is available from the editors. The Journal is published in English, but articles may also be submitted in Spanish or Portuguese; if the article is accepted, translation into English will be the responsibility of the author. Tables, diagrams and maps may be included by arrangement with the editors. The Journal only publishes original contributions; translations of articles already published will not be accepted. Each contributor will receive, free of charge, 25 offprints of the article and a copy of the issue of the Journal in which it appears.

The Journal publishes book reviews in each issue. Not all books received can be reviewed and editorial policy gives preference to substantial reviews of books regarded as of major importance for the disciplines covered by the Journal.

All contributions and editorial correspondence should be addressed to Joumal of Latin American Studies, Institute of Latin American Studies, 3 I Tavistock Square, London, $\mathrm{WC}_{\mathbf{1}} \mathrm{H}_{9} \mathrm{HA}$.

\section{COPYRIGH'T}

COPYING. This journal is registered with the Copyright Clearance Center, 222 Rosewood Drive, Danvers, MA or923. Organisations in the USA who are also registered with C.C.C. may therefore copy material (beyond the limits permitted by sections 107 and 108 of US copyright law) subject to payment to C.C.C. of the per-copy fee of $\$ 7.50$. This consent does not extend to multiple copying for promotional or commercial purposes. Code $0022-216 x / 96 \$ 7.50+.10$.

ISI Tear Sheet Service, 3501 Market Street, Philadelphia, Pennsylvania 19104, USA, is authorised to supply single copies of separate articles for private use only.

Organisations authorised by the Copyright Licensing Agency may also copy material subject to the usual conditions.

For all other use, permission should be sought from Cambridge or the American Branch of Cambridge University Press.

\section{CAMBRIDGE UNIVERSITY PRESS}

The Pitt Building, Trumpington Street, Cambridge CB2 I RP

40 West 2oth Street, New York, NY IOOI I-42 I I, USA

Io Stamford Road, Oakleigh, Melbourne 3 I66, Australia

Printed in Great Britain by the University Press, Cambridge 


\section{Journal of}

\section{Latin American Studies}

Volume 28 Part 2 May 1996

\section{ARTICLES}

Guerrillas and the State: The Role of the State in the

Colombian Peace Process

LAWRENCE BOUDON

The Formation and Transformation of Political Identity:

Leaders of the Chilean Left, 1968-1990

KATHERINE HITE

\section{CENTRAL AMERICA: NEW ASSESSMENTS}

The Institutional Foundations of Democratic Cooperation in Costa Rica

FABRICE E. LEHOUCQ

Crown Colony as Banana Republic: The United Fruit Company in British Honduras, $1900-1920$

MARK MOBERG

Horse Thieves to Rebels to Dogs: Political Gang Violence and the State in the Western Segovias, Nicaragua, in the Time of Sandino, I926-I934

MICHAEL J. SCHROEDER

Constructing the Limits of State Violence in Central America:

Towards a New Research Agenda

ROBERT H. HOLDEN

\section{COMMENTARY}

Prospects for Democratisation in a Post-Revolutionary Setting:

Central America

CARLOS M. VILAS

BOOK REVIEWS

NEW BOOKS RECEIVED 